\title{
BP-CI in the treatment of patients with stage IV breast cancer: a randomized, double-blind, placebo-controlled multicenter study and an additional open-label treatment phase [Corrigendum]
}

\author{
Larsen S, Butthongkomvog K, Manikhas A, et al. Breast \\ Cancer: Targets and Therapy. 2014;6:179-189.
}

On page 184 there is an error in Figure 3A. The error consists of a yellow bar at +16 days in the placebo group. The correct Figure 3A appears here:

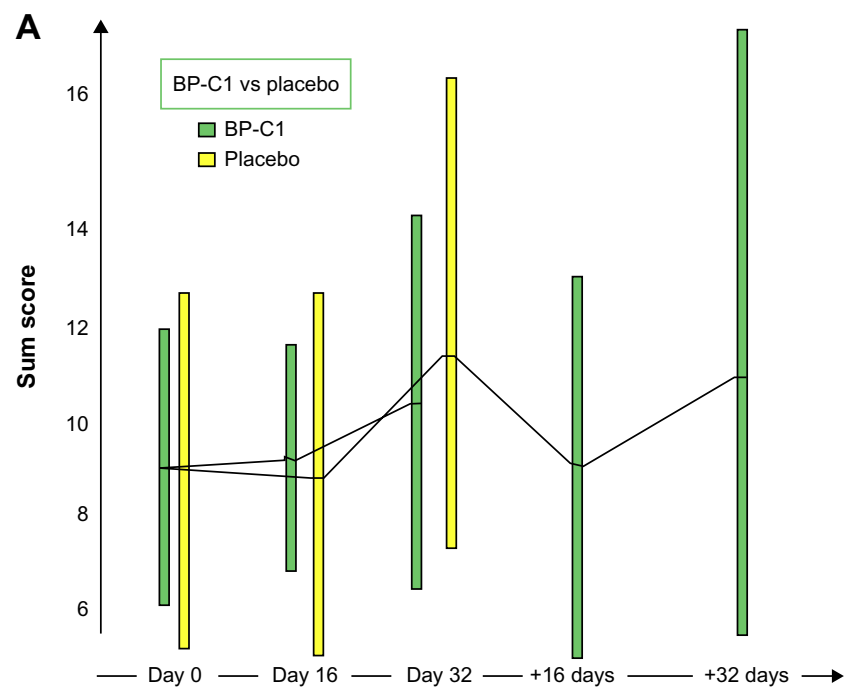

Figure 3A.

\section{Publish your work in this journal}

Breast Cancer: Targets and Therapy is an international, peerreviewed open access journal focusing on breast cancer research, identification of therapeutic targets and the optimal use of preventative and integrated treatment interventions to achieve improved outcomes, enhanced survival and quality of life for the cancer patient.
View the full aims and scopes of this journal here. The manuscript management system is completely online and includes a very quick and fair peer-review system, which is all easy to use. Visit http:// www.dovepress.com/testimonials.php to read real quotes from published authors. 